\title{
Robert Klimek
}

\section{OD POGAŃSKIEGO MIEJSCA KULTU DO CHRZEŚCIJAŃSKIEGO SANKTUARIUM - ŚWIĘTA LIPKA I GIETRZWAŁD NA TLE KRAJOBRAZU SAKRALNEGO WARMII}

\author{
Słowa kluczowe: Gietrzwałd, Święta Lipka, sanktuaria, Warmia, pogańskie miejsca kultu \\ Schlüsselwörter: Gietrzwałd, Święta Lipka, Heilgtümer, Ermland, heidnische Kultstätte \\ Keywords: \\ Gietrzwałd, Święta Lipka, sanktuaries, Warmia, pagan cult places
}

Diecezja warmińska została powołana do życia 29 lipca 1243 r. Wówczas na polecenie papieża Innocentego IV legat Wilhelm z Modeny dokonał we włoskim mieście Anagni podziału obszaru ziem pruskich na cztery diecezje: chełmińską, pomezańską, warmińską i sambijską. Obszar diecezji warmińskiej od zachodu wyznaczał Zalew Wiślany, od północy Pregoła, na południu granicą było jezioro Drużno i rzeka Wąska. Od strony wschodniej diecezja miała dochodzić aż do Litwy ${ }^{1}$. Trzy biskupstwa pruskie (pomezańskie, warmińskie i sambijskie) miały zostać uposażone trzecią częścią majątków ziemskich, które istniały w poszczególnych diecezjach. Pozostałe miały należeć do zakonu krzyżackiego. Taki podział dóbr przeprowadzono $\mathrm{z}$ uwagi na znaczny wysiłek militarny, jaki ciążył na Krzyżakach w związku z walką przeciwko Prusom. Pierwszy biskup warmiński Anzelm wybrał dla siebie środkową część swojego władztwa kościelnego. Podział diecezji warmińskiej na część biskupią i zakonną przebiegał w kilku etapach. Po raz pierwszy doszło do porozumienia 27 kwietnia 1251 r. $^{2}$, a następnie 27 grudnia 1254 r. Obszar Warmii biskupiej, jako dominium biskupa, ostatecznie został ustalony w 1374 r. ${ }^{3}$ Wcześniej, przed podbojem tej ziemi przez

${ }^{1}$ Codex diplomaticus Warmiensis oder Regesten und Urkunden zur Geschichte Ermlands (dalej: CDW), hrsg. von C. P. Woelky u. J. M. Saage, Bd. 1, Mainz 1860, nr 5, ss. 5-8; CDW, Bd. 1, nr 6, ss. 8-9; CDW, Bd. 1, regest nr 11, s. 3; A. Szorc, Dominium warmińskie 1243-1772. Przywilej i prawo chełmińskie na tle ustroju Warmii, Olsztyn 1990, s. 23.

${ }^{2}$ CDW, Bd. 1, nr 26, ss. 47-49.

${ }^{3}$ CDW, Bd. 2, Mainz 1864, nr 202. 
zakon krzyżacki, obszar dominium warmińskiego zajmowany był przez cztery plemiona pruskie: Warmów, Pogezanów, Bartów i Galindów.

Według Piotra Dusburga Prusowie nie znali pojęcia Boga i czcili każde stworzenie lub zjawisko: słońce, księżyc i gwiazdy, pioruny, ptaki, zwierzęta czworonożne, a nawet ropuchę. Za święte uważali gaje, pola i wody do tego stopnia, że nie odważyli się w nich wycinać drzew, uprawiać ziemi ani łowić ryb. Piotr Dusburg wspominał także, że Prusowie mieli swoje centrum kultowe zwane Romowe, które miało się znajdować $\mathrm{w}$ Nadrowii ${ }^{4}$. Na podstawie średniowiecznych zapisów toponomastycznych można wysnuć wnioski, że na Warmii występowały święte gaje, pola oraz święte wody, wśród których można znaleźć jeziora, niewielkie rzeki oraz źródła. Odnotować należy także ważne pod względem kultowym wzgórza i kamienie. Część z nich została z czasem przejęta przez Kościól. Na niektórych dawnych miejscach pogańskiego kultu w Prusach z czasem zaczęły powstawać świątynie chrześcijańskie. Podobną sytuację można zaobserwować na obszarze dominium warmińskiego. Podczas przejmowania dawnego miejsca kultu pogańskiego przez Kościól starano się, ảbỹ nowa świątynia wybudowana w miejscu starej była bardziej okazała ${ }^{5} 7$ lutego 1249 r. podpisano tzw. ugodę dzierzgońską. Prusowie obiecali w niej zbudowane przez siebie kościoły tak wewnątrz wystroić, aby dla modlących się w nich ludzi były bardziej atrakcyjne niż pogańskie świątynie w lasach. Prusowie zobowiązali się do odbudowy zburzonych przez siebie w czasie powstań kościołów w terminie do Zielonych Świątek - Pentecosten ${ }^{6}$. W literaturze znane są przykłady adaptacji ważnych ośrodków kultu pogańskich Prusów przez Kościół. Wśród nich można wymienić Świętą Siekierkę i Patollen koło Domnowa, gdzie w latach siedemdziesiątych XIV w. na polecenie wielkiego mistrza Winryka Kniprode wybudowano klasztory ${ }^{7}$. Można domniemywać, że także na Warmii niektóre kościoły zbudowano w pobliżu miejsc związanych z pogańskim kultem. Mogło tak być m.in. w: Ełdytach, Lidzbarku Warmińskim, Plutach i Świątkach. Pruskie pole campus Swenkiten, ${ }^{8}$ dzisiejsze Świękity, odnotowane w 1294 r., było położone w pobliżu wsi kościelnej Ełdyty, założonej już w 1289 r. Wedle odnotowanej przez Victora Röricha tradycji, w Ełdytach znajdować się miał w okresie przedkrzyżackim ośrodek

${ }^{4}$ Petrus de Dusburgk, Chronica terrae Prussiae, Kraków 2007, s. 52.

${ }^{5}$ M. Kosman, Zanik pogaństwa w Prusach, Komunikaty Mazurskie-Warmińsko (dalej KMW), nr 1, 1976, s. 22.

${ }^{6}$ Preussisches Urkundenbuch, hrsg. von A. Philippi, Königsberg 1882, Bd I/1, nr 218: Et promiserunt omnes predicti, quod dictas ecclesias edificabunt adeo honorabiles et decoras, quod plus videbuntur delectari in oracionibus ac oblacionibus factis in ecclesiis quam in silvis.

${ }^{7}$ Die Chronik Wigands von Marburg, w: Scriptores rerum Prussicarum, hrsg. von T. Hirsch, M. Toeppen, E. Strehlke, Bd. 2, Leipzig 1863, s. 468; S. Grunau, Preussische Chronik, Bd. 1, Leipzig 1876, ss. 347-348. Zdaniem Grunaua klasztor Świętej Trójcy w Patollen powstał w miejscu Ryckoyot - Romowe, gdzie znajdował się dąb, przy którym czczono bóstwa Prusów: Patollo, Potrimpusa i Perkuna.

${ }^{8} \mathrm{CDW}, \mathrm{Bd} .1, \mathrm{nr} 93$. 
kultu Prusów9 ${ }^{9}$ Dowodem na to miał być zbudowany tam jako jeden z pierwszych na Warmii biskupiej kościół ${ }^{10}$. Niemiecka nazwa miasta Lidzbark Warmiński (Heilsberg) najprawdopodobniej pochodzi od jakiejś kultowej góry znajdującej się w jego okolicy. Po raz pierwszy nazwa Heilsberg pojawia się właśnie w nadaniu dla wsi Ełdyty z 1289 r. ${ }^{11} \mathrm{Na}$ podstawie pewnych zapisów źródłowych można wysnuć tezę, że poszukiwanym świętym miejscem jest Krzyżowa Góra. Według pierwszej wzmianki z 1390 r. była to góra koło Pilnika, która stanowiła własność biskupów i w przeszłości prawdopodobnie była ważnym miejscem dla Prusów: quique mons fuit antiquitus et est de proprietate nostra et ecclesie nostre Warmiensis $^{12}$. W innym dokumencie, pochodzącym z 1431 r., stwierdzającym przekazanie miastu dodatkowych ziem wydzielonych $\mathrm{z}$ posiadłości biskupich, znajduje się informacja, że na górze w pobliżu Pilnika został ulokowany krzyż: mons ubi crux lokata. W czasach nowożytnych na Krzyżowej Górze znajdowała się kaplica: capella sanctae crucis ${ }^{13}$. Prawdopodobnie miejscem kultu pogańskiego były także okolice dzisiejszej wsi Świątki (Heiligental), której niemiecką nazwę możemy przetłumaczyć jako „Święta Dolina”. W Świątkach dosyć wcześnie, bo juz w 1347 r., został wymieniony kościół parafialny ${ }^{14}$. W Plutach kościół powstał w pobliżu pogańskiego świętego gaju (sanctus nemus) ${ }^{15}$. Na jego obszarze znajdowały się źródła, które miejscowa ludność uznawała za lecznicze ${ }^{16}$.

\section{Święta Lipka}

Jednym z miejsc, które było wcześniej otaczane pogańskim kultem, a z czasem stało się chrześcijańskim sanktuarium, jest Święta Lipka. Co prawda sama miejscowość nie leży na Warmii, lecz przy jej granicy, ale miała z nią bardzo ścisły związek. Wiele wskazuje na to, że przed ostatecznym rozwiązaniem proble-

${ }^{9}$ V. Röhrich, Die Kolonisation des Ermlandes, Zeitschrift für die Geschichte und Altertumskunde Ermlands (dalej: ZGAE), 1901, Bd. 13, s. 412.

${ }^{10}$ P. Kawiński, Organizacja pogańskiej przestrzeni sakralnej Prusów na tle osadnictwa w okresie plemiennym - przykład Pomezanii, Pogezanii i Warmii, Pruthenia, t. 6, 2011, ss. 106-107.

${ }^{11}$ CDW, Bd. 1, nr 79. Dokument ten powstał na zamku w Lidzbarku Warmińskim - datum in Castro nostro Heilsberg.

${ }^{12}$ CDW, Bd. 3, nr 243. Na ten zapis zwrócił już uwagę Jan Ptak, Wojskowość średniowiecznej Warmii, Olsztyn, 1997, s. 144.

${ }^{13}$ Monumenta Historiae Warmiensis, Quelen zur Kultur- und Wirdschaftsgeschichte des Ermlands, Bd 4, hrsg von V. Röhrich, A. Poschmann, Braunsberg 1915, s. 115; J. Enders, Tabula geographica episcopatum warmiensem in Prussia, Elbing 1755 - Kreutzkirche.

${ }^{14}$ A. Olczyk, Sieć parafialna biskupstwa warmińskiego do roku 1525, Lublin 1961, s. 87 - pierwsza pośrednia wzmianka o istnieniu tu kościoła: villam parochialem Heilgental, CDW Bd. 2, nr 99.

${ }^{15}$ CDW, Bd. 1, nr 216, 221.

${ }^{16}$ Museum für Vor- und Frühgeschichte, Preußischer Kulturbesitz, PM-A 1138/1 Plauten, Kr. Braunsberg; Meßtischblatt 1787, Lichtenau, 1:25 000, 1932 - „Heilbr.” 
mu granicy posiadłości biskupa warmińskiego i państwa krzyżackiego w $1374 \mathrm{r}$. obszar ten znajdował się w jurysdykcji dominium. Pewne informacje na temat przebiegu dawnej granicy Warmii biskupiej dostarcza plan archiwalny Świętej Lipki z 1612 r., wykonany przez niejakiego Kretzmera, który był przysięgłym mierniczym biskupa ${ }^{17}$. Otóż na tym planie rzeka wypływająca $\mathrm{z}$ jeziora Wirbel jest opisana jako stara granica: Fluvius antiquus Limitaris. Ten zapis podaje nowe fakty odnośnie do przebiegu granicy Warmii biskupiej sprzed 1374 r. Prawdopodobnie biskup uważał, że przechodziła ona od punktu wyznaczonego w lesie Krakocin, położonego jedną milę od zamku w Reszlu, do jeziora Wirbel. Dalej, w kierunku południowym, granicą była rzeka wypływająca z Wirbel i jezioro Dajnowa, na którego północnym krańcu leżała Święta Lipka, na południowym zaś - Pilec ${ }^{18}$.

Pierwsza wzmianka w źródłach o okolicy Świętej Lipki pochodzi z $1340 \mathrm{r}$. W tym roku na obszarze Barcji (in terra Barthen), nad jeziorem Dejnowa (Denow), wójt Henryk Luter dokonał dwóch nadań ziemskich, jedno 6 łanów, zaś drúgie 28 łanów $^{19}$. W pierwszym $\mathrm{z}$ nadan zawarta jest informacja, jakoby okolica, gdzie powstała osada, jest niebezpieczna $z$ uwagi na przebywających tam pogan: propter paganos, et dei inimicos, qui ibidem valde sunt timendi. W tym czasie trwała postępująca akcja osadnicza. Powstawały kościoły i parafie, ale na podstawie tego zapisu możemy przypuszczać, że na niektórych obszarach kult pogański dalej był żywy. Najprawdopodobniej było też tak w okolicy dzisiejszej Świętej Lipki. Jest więcej symptomów, które wskazują na fakt, że pogańskie sanktuarium istniało tam jeszcze przed podbojem tych ziem przez Zakon. Święta Lipka położona jest nad jeziorem Dejnowa, którego pierwsza odnotowana nazwa (Denow - 1340 r.) może świadczyć o jego kultowej roli. Według Georga Gerullisa nazwa jeziora nawiązuje do wyrażeń: Daina, Dainawa, Dainis, czyli do rytualnych pieśni, tańca, co również potwierdził rosyjski językoznawca Wladimir Toporow ${ }^{20}$. W języku litewskim i łotewskim daina oznacza „pieśń”. Znacze-

${ }^{17}$ Archiwum Archidiecezji Warmińskiej w Olsztynie, Mappa bonorum sacrae Tiliae confecta a Jurato Geometra D. Kretzmer, 1612, sygn. M 209.

${ }^{18}$ R. Klimek, Ślady średniowiecznej granicy Warmii między Reszlem a Świętą Lipką, Studia Geohistorica, 2016, nr. 4, s. 42 .

${ }^{19}$ CDW Bd, 1, nr 305 i 306. Zdaniem wydawców CDW, drugie z nadań dotyczyło Świętej Lipki. W literaturze przedmiotu spotykamy się także z opinią, że obszar 28 łanów to dzisiejszy Pilec, zaś 6 łanów było położone przy wypływie rzeki Dajna z jeziora, patrz Johannis Plastwici, Chronicon de vitis Episcoporum Warmiensium, w: Scriptores rerum Warmiensium, Bd. 1, hrsg. von C.P. Woelky, J. M. Saage, Braunsberg 1866, ss. 67-68, przyp. 34. Uważam, że w obydwu propozycjach pojawiają się nieścisłości. Moim zdaniem nadanie 28 łanów miało miejsce na obszarze Pilca, zaś 6 łanów tam, gdzie obecnie jest Święta Lipka, czego potwierdzeniem jest zapis o poganach. W miejscu, gdzie wypływa Dajna z jeziora wydaje się, że nie było w tym czasie osadnictwa.

${ }^{20}$ G. Gerullis, Die altpreussischen Ortsnamen, Berlin-Leipzing 1922, s. 27; В. Н. Топороb, Прусский язык. Слоьарь А-Д, Москва 1975, s. 290. 
nie hydronimu Denow przypuszczalnie możemy wiązać z „rytualnym tańcem ze śpiewaniem"21. Między Świętą Lipką a Reszlem, już po stronie Warmii biskupiej, znajduje się wieś Ramty, odnotowana w 1389 r. jako Ramboten ${ }^{22}$. Nazwy typu Rombhota oznaczały święte drzewa, które były nietypowo zrośnięte ${ }^{23}$. W tej sytuacji można domniemywać, że teren ten tworzył większą strefę sacrum, obejmującą las przy dzisiejszych Ramtach i jezioro Dajnowa z centralnym ośrodkiem w Świętej Lipce. Należy także zaznaczyć, że lipa była uważana za święte drzewo Prusów, pierwiastek żeński - odwrotnie niż dąb, który był utożsamiany z symboliką męską. O świętych lipach czczonych przez Prusów pisali Kaspar Hennenberger i Mateusz Praetorius. Taka wyjątkowa lipa znajdowała się w Skalowii, we wsi Schackuhnen, nad rzeką Rusna ${ }^{24}$. Według relacji Kaspara Steina - między Rastenburgiem, a Reszlem rosła rozłożysta lipa poświęcona Najświętszej Marii, którą znano tam od bardzo dawnych czasów: tilia ramosa quedam D. Mariae dedicata, quae antiquitus ibi stetit ${ }^{25}$. Jej związek z dawnym kultem pogańskim był także znany w nowożytnej historiografii ${ }^{26}$. Według ks. Jana Leo, w Świętej Lipce znajdowała się mocno rozgałęziona lipa, „wyjątkowo upodobana przez Boga”. Lipa miała być domem bożym, drabiną wzniesioną do nieba, po której zstępując i wstępując aniołowie zanoszą ludzkie modlitwy i śluby, a znoszą z niebios łaskę ${ }^{27}$.

Święta Lipka od XV w. była miejscem pielgrzymek. Źródłowe świadectwo o pielgrzymce mamy już z 1473 r. Wówczas kapłan Maciej ze Śluzowa ubolewał, że wierni z diecezji płockiej pielgrzymują tam, chociaż miejsce to nie było wówczas obdarzone żadnymi odpustami ${ }^{28}$. Kronikarz Lukas David pisał, że będąc małym chłopakiem uczestniczył ze swoją matką w pielgrzymce do Świętej Lipki. Opisał jak pątnicy kładli na wagę mięso w ofierze - w konkretnych intencjach. Przytoczył przykład chorowitego chłopca, którego posadzono na jednym krańcu szali wagi, zaś na drugi kładziono w ofierze mięso, do momentu aż jego waga przekroczyła wagę chłopca. W ten sposób wierzono, że ofiara spełniona w Świę-

\footnotetext{
${ }^{21}$ A. Vanagas, Lietuvių hidronimų etimologinis žodynas, Vilnius 1981, s. 79.

${ }^{22}$ CDW, Bd. 2, nr 497 - Ramothen (1374); CDW Bd. 3, nr 229; V. Röhrich, Die Kolonisation des Ermlandes, ZGAE, Bd 21, 1923, ss. 279-280.

${ }^{23}$ M. Praetorius, Deliciae Prussicae oder Preussische Schaubühne, Bd. 3, Vilnius 2006, ss. 108-110; C. Hartknoch, Alt- und Neues Preüßen, Frankfurt-Leipzig 1684, s. 291.

${ }^{24}$ C. Hennenberger, Erclerung der preussischen grössern Landtaffel oder Mappen, Königsberg 1595, s. 416, M. Praetorius, Deliciae Prussicae, s. 108.

${ }^{25}$ A. Mierzyński, Źródła do mytologii litewskiej, Warszawa 1892, s. 62; J. Powierski, Bogini Kurkő i niektóre aspekty społeczno-gospodarcze wierzeń Pruskich, Prussica t. 1, Malbork 2003, s. 136.

${ }^{26}$ E. Tidick, Beiträge zur Geschichte der Kirchen-Patrozinien im Deutschordenslande Preußen bis 1525, ZGAE Bd. 22, 1926, ss. 361-362.

${ }^{27}$ J. Leo, Dzieje Prus, Olsztyn 2008, ss. 24-25. 2006, s. 78.

${ }^{28}$ J. Hochleitner, Przydrożne pomniki kultu religijnego Świętej Lipki i okolic, Studia Angerburgica t. 11,
} 
tej Lipce uleczy chorego ${ }^{29}$. Z tym miejscem związana jest też legenda. Pewien skazany na śmierć więzień otrzymał w celi od Matki Boskiej kawałek drewna, z którego wyrzeźbił jej figurkę. Został ułaskawiony i wyrzeźbioną figurkę zawiesił na pierwszej napotkanej lipie przy drodze z Rastenburga do Reszla. Próby przeniesienia figurki do kościoła w Rastenburgu kończyły się samowolnym powrotem figurki na miejsce. Rozchodziły się wieści o łaskach doznawanych przez pielgrzymów, co spowodowało coraz większy napływ pątników. Na podstawie najstarszych ikonograficznych przekazów uważa się, że kaplica była murowana i okalała pień lipy z figurką. W 1519 r. do Świętej Lipki przybył wielki mistrz krzyżacki Albrecht von Hohenzollern w towarzystwie biskupa sambijskiego J. Polentza. W 1526 r. ten sam książę Albrecht zakazał wszelkich pielgrzymek i nakazał zburzenie kaplicy. Chcąc odstraszyć pątników, ustawiono w tym miejscu szubienicę. Biskup Szymon Rudnicki wykupił z rąk protestanckich właścicieli to miejsce, od 1639 r. teren był własnością kapituły fromborskiej pod administracją jezuitów, od 1640 r. rozpoczęły się regularne pielgrzymki do Świętej Lipki ${ }^{30}$.

\section{Gietrzwałd}

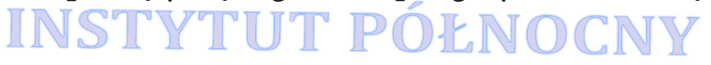

W 1877 r. na klonie rosnącym obok kościoła w Gietrzwałdzie miało miejsce objawienie Matki Boskiej dwóm dziewczynkom. W setną rocznicę tego wydarzenia biskup Józef Drzazga ogłosił dekret zatwierdzający kult objawień, nie wykluczając ich nadprzyrodzonego charakteru ${ }^{31}$. Wiele jednak wskazuje, że miejsce to było uświęcone dużo wcześniej. Już w drugiej połowie XVI w. spotykamy się w Gietrzwałdzie z kultem Matki Boskiej. Świadczy o tym zwyczaj przyozdabiania welonem jej obrazu, znajdującego się w bocznym ołtarzu świątyni. Potem obraz ten przeniesiono do ołtarza głównego, co świadczy o wzroście kultu. Protokół wizytacyjny z 1680 r. informuje o odsłanianiu wizerunku NMP w oktawie święta Narodzenia Matki Bożej, czyli w uroczystość patronalną kościoła. Należy uznać, że w XVI-XVIII w. sanktuarium maryjne w Gietrzwałdzie nie było typowym kościołem pielgrzymkowym, jednak kult Matki Boskiej był tutaj żywy ${ }^{32}$. Kościół w Gietrzwałdzie po raz pierwszy został wymieniony w 1352 r. - zarezerwowano na jego potrzeby 5 wolnych łanów ${ }^{33}$. Nie można jednak wykluczyć związków tego miejsca z pobliskim jeziorem Giłwa (Rentyńskie) oraz

\footnotetext{
${ }^{29}$ L. David, Preussische Chronik, hrsg. E. Hennig, Bd. 1, Königsberg 1812, ss. 151-152.

${ }^{30}$ J. Hochleitner, Przydrożne pomniki kultu, s. 79.

${ }^{31}$ S. Achremczyk, Warmia, Olsztyn 2011, ss. 383-384.

${ }^{32}$ A. Kopiczko, Ustrój i organizacja diecezji warmińskiej w latach 1525-1772, Olsztyn 1993, ss. 189-190.

${ }^{33}$ CDW, Bd. 2, nr 179.
} 
z kultem Prusów. Jego nazwa (Gilbing) występuje w spisanej w Iura Pruthenorum formule gajenia pruskiego sądu ziemskiego przez wolnych Prusów z okolicy Olsztynka: „Gaję ten nasz pruski sąd głęboko jak Gilbing, wysoko jak dąb, mocno jak kamień, czy to będzie słuszne czy niesłuszne"34. Jezioro to występuje w źródłach już od 1346 r. ${ }^{35}$ Jego nazwa pochodzi od wyrazu gilus, co oznacza „głęboki”36. Jan Powierski zwraca uwagę, że rota przysięgi posiada rdzeń oznaczający głębokość. Z roty tej wyprowadza wniosek o sakralnej roli tego jeziora. W związku z tym nasuwa się przypuszczenie, że tutejszy archaiczny ośrodek kultowy znalazł swoją kontynuację w kulcie maryjnym, w blisko położonym koło jeziora Gietrzwałdzie. Nie byłby to jedyny przykład odradzania się ludowego kultu chrześcijańskiego w miejscu dawnego kultu pogańskiego ${ }^{37}$. Rota przysięgi Prusów, w której występuje dąb (święte drzewo), kamień (symbol trwałości) i jezioro Gilbing, pozwala domniemywać, że był to zbiornik wodny o znaczeniu sakralnym. Na fakt występowania tryptyku składającego się z drzewa, ołtarza i kamienia zwrócił już uwagę Mircea Eliade. Kamień wyobrażał rzeczywistość jako trwałą i niezniszczalną. Drzewo ze swoją periodyczną regeneracją wyrażało świętą moc w porządku życia. Tam, gdzie wody uzupełniały krajobraz, wyrażały ukryte możliwości, zarodki czy oczyszczenie. "Mikrokosmiczny krajobraz” ograniczyl się z czasem do jednego, najważniejszego z tych elementów - do drzewa. W dawnych wierzeniach drzewo było osią świata. Stanowiło pomost między niebem, ziemią, a nawet piekłem ${ }^{38}$. Nasuwa się w związku z tym wniosek, że tutejszy archaiczny ośrodek kultowy znalazł swoją kontynuację w blisko położonym Gietrzwałdzie. Nie byłby to jedyny przykład tworzenia ludowego kultu chrześcijańskiego w miejscu dawnego kultu pogańskiego ${ }^{39}$.

\section{Podsumowanie}

Wraz z rozwojem osadnictwa na ziemiach pruskich w XIV-XV w., mimo że powstawało coraz więcej kościołów i parafii, to jednak część Prusów nadal, najczęściej w ukryciu, oddawała cześć dawnym bóstwom. W dokumentach źró-

\footnotetext{
${ }^{34}$ Iura Pruthenorum, opr. J. Matuszewski, Toruń 1963, ss. 60-61: Ich hege diese unser Preussische ding tiff als Gilbing, hoc hals ein Eichelbaum, fest als ein sten, es sey recht oder unrecht.

${ }^{35}$ CDW Bd 2, nr 68: lacubus Gilbes - 1346; CDW Bd. 2, nr 179 i 180: lacubus Gilbde 1352.

${ }^{36}$ V. Mažiulis, Prūsų kalbos etimologijos žodynas, Vilnius 2013, s. 239, gillin, gilus; W. Smoczyński, Słownik etymologiczny języka litewskiego, Wilno 2007, s. 178: gilus,

${ }^{37}$ J. Powierski, Drugi tom słownika języka pruskiego, w: Prussica, t. 1, Malbork 2003, s. 392; P. Kawiński, Organizacja pogańskiej przestrzeni sakralnej Prusów, s. 108.

${ }^{38}$ M. Eliade, Traktat o historii religii, Warszawa 2009, ss. 281-283.

${ }^{39}$ R. Klimek, Miejsca kultu Prusów na Warmii biskupiej, KMW, nr 3, 2015, s. 371.
} 
dłowych można spotkać się z nakazami wydawanymi przez biskupów, aby Prusowie porzucili starą wiarę i uczęszczali do kościołów. Najwyraźniej dalej świętowali oni w lasach i ponownie chrzcili w rzekach swoje dzieci ${ }^{40}$. Niektóre $\mathrm{z}$ takich miejsc z czasem były adoptowane przez Kościół. Dawne pogańskie bóstwa zastępowano chrześcijańskimi. W średniowieczu na zachodzie Europy, już od XI w., zaznacza się silny rozwój kultu maryjnego. Powstają liczne sanktuaria, niejednokrotnie na miejscu dawnych ośrodków pogańskich ${ }^{41}$. Z czasem kult maryjny dotarł także na obszar Prus, gdzie czasem dochodziło do adaptacji przez Kościół dawnych miejsc pogańskich. Taka transformacja miała miejsce m.in. w Świętej Lipce co najmniej od XV w. Poza Warmią analogicznym przykładem mogą być Lipy pod Lubawą. Jak wynika $\mathrm{z}$ wizytacji przeprowadzonej w latach 1667-1672, w Łąkach koło Bratianu znajdowało się kultowe miejsce poświęcone bogini Majumy. Prusowie powracający z pielgrzymek do Łąk zatrzymywali się również w lipowym gaju koło Lubawy, gdzie odpoczywali i odprawiali religijne obrzę$\mathrm{dy}^{42}$ : Najwyraźniej chrześcijaństwo, niszcząc w pierwszej akcji symbole pogańskie, w dłuższej perspektywie korzystało jednak z lokalnej tradycji sakralnej przypisywanej świętym miejscom pogaństwa. W ten oto sposób zawłaszczało utrwaloną wśród miejscowych populacji moc. Znajdowało to wyraz przede wszystkim we wznoszeniu kościołów, które przejmowały część tradycji miejsc dawnych kultów ${ }^{43}$.

\section{Robert Klimek, Von der heidnischen Kultstätte bis zum christlichen Heiligtum - Święta Lipka (Heilige Linde) und Gietrzwałd (Dietrichswalde) in der sakralen Landschaft Ermlands}

\section{Zusammenfassung}

Święta Lipka (Heilige Linde) und Gietrzwałd (Dietrichswalde) gehören heute zu den bekanntesten Marien-Sanktuarien Ermlands. Dietrichswalde liegt im Süden des Ermlands, Heilige Linde - außerhalb seiner östlichen Grenze, dieser Ort ist jedoch eng mit dem Ermland verbunden.

Man vermutet, dass manche Kirchen im Ermland in der Nähe der heidnischen Kultstätten gebaut wurden. Dies könnte man auf solche Orte wie Ełdyty (Elditten), Lidzbark Warmiński (Heilsberg), Pluty (Plauten) und Świątki (Heilligental) beziehen. Daraus wird ersichtlich, dass das Christentum in seiner ersten Phase der Bekämpfung der heidnischen Symbole in großem Maße die lokalen sakralen Traditionen nutzte, die mit den heidnischen Kultstätten verbunden waren. An diesen Orten wurden Kirchen gebaut, die einigermaßen tradierte Heiligtümer ersetzten und sakrale Traditionen fortsetzten, wie z. B. in Heilige Linde und in Dietrichswalde. Die erste Erwähnung der Heiden am See Dejnowa (in den Quelen: Denow) stammt aus dem Jahr 1340. Es war allgemein bekannt, dass schon seit dem 15. Jahrhundert üblich war, zu dem Lindenbaum zu pilgern, den die Wallfahrer für heilig hielten, weil hier die Mutter Gottes erschienen wäre.

${ }^{40}$ Por. A. Radzimiński, Chrystianizacja i ewangelizacja Prusów. Historia i źródła, Toruń 2011, ss. 97-100.

${ }^{41}$ J. Cheleni, H. Branthomme, Boże drogi. Historia pielgrzymek chrześcijańskich, Warszawa 1996, s. 129.

${ }^{42} \mathrm{G}$. Białuński, O zasiedleniu ziemi lubawskiej w okresie przedkrzyżackim $w$ świetle źródeł pisanych $i$ toponomastycznych, Pruthenia, t. 4, 2008, s. 307.

${ }^{43}$ P. Urbańczyk, Władza i polityka we wczesnym średniowieczu, Wrocław 2008, s. 181. 
Bereits im 15. Jahrhundert stand neben der Linde eine Kapelle. Seit 1639, als sich hier die Jesuiten niederließen, wurde Heilige Linde zum wichtigen Zentrum des Maria-Kultes. Die alte heidnische Kultstätte in der Nähe von Dietrichswalde kann der Text des Prußen-Schwurs in Iura Pruthenorum bezeugen, in dem u.a. der Name des in der Nähe liegenden Gilbing-Sees (ggw. Rentyńskie), sowie der Stein und die Eiche erwähnt wurden. Daraus kann man schließen, dass die hiesige Kultstätte ihre Fortsetzung in Dietrichswalde fand, wo 1877 eine MariaErscheinung stattfand.

Übersetzt von Alina Kuzborska

\section{Robert Klimek, From a pagan cult site to a Christian sanctuary - Święta Lipka and Gietrzwałd within the sacred landscape of Warmia}

\section{Summary}

Święta Lipka and Gietrzwałd are amongst the most famous Marian sanctuaries associated with Warmia. Gietrzwałd is located in the southern part of Warmia, and Święta Lipka just outside its eastern border, but its fate was inseparably connected with Warmia.

It is presumed that some churches in Warmia were built near places associated with pagan worship. These could be, amongst others: Ełdytach, Lidzbark Warminski, Plutach and Świątkach. Apparently, Christianity, which inititally destroyed pagan symbols, over the long term took advantage of local sacred traditions attributed to sacred pagan sites. This was primarily expressed in the construction of churches that took over part of the traditions of places of ancient worship, such as Święta Lipka and Gietrzwałd. The first information concerning pagans at Lake Dejnowa (Denow) dates back to 1340. It is widely known that since the 15th century there was quite a common pilgrimage to the linden tree, which pilgrims considered sacred due to the appearance of the Virgin Mary at the site. Already in the 15 th century, there was a chapel next to the linden. The Jesuits established themselves there from 1639. Since then, Lipka has become an important centre of Marian devotion. The presence of a cult site near Gietrzwałd can be indicated by the text of the Prussian oath written in the Iuera Pruthenorum, in which the nearby Lake Rentyńskie (formerly Gilbing) appears: "I put this Prussian court deep as Gilbing, as high as the oak, as strong as stone, if this is correct or incorrect" The conclusion is that the archaic cult centre continued in nearby Gietrzwałd. In 1877 a Marian apparition was seen here.

Translated by Aleksander Pluskowski

mgr Robert Klimek

Ośrodek Badań Naukowych

im. Wojciecha Kętrzyńskiego w Olsztynie

robertusklimek@wp.pl

Bibliografia

Źródła archiwalne

Archiwum Archidiecezji Warmińskiej w Olsztynie

Mappa bonorum sacrae Tiliae confecta a Jurato Geometra D. Kretzmer, 1612, sygn. M 209.

Museum für Vor- und Frühgeschichte, Preußischer Kulturbesitz

PM-A 1138/1 Plauten, Kr. Braunsberg; Meßtischblatt 1787, Lichtenau, 1:25 000, 1932. 
Źródła drukowane

Codex diplomaticus Warmiensis

1860-1874. Codex diplomaticus Warmiensis oder Regesten und Urkunden zur Geschichte Ermlands, hrsg. von C. P. Woelky u. J. M. Saage, Bd. 1-3, Mainz.

Iura Pruthenorum

1963. Iura Pruthenorum, opr. J. Matuszewski, Toruń.

Monumenta Historiae Warmiensis

1915. Monumenta Historiae Warmiensis, Quelen zur Kultur- und Wirdschaftsgeschichte des Ermlands, Bd. 4, hrsg. von V. Röhrich, A. Poschmann, Braunsberg.

Preussisches Urkundenbuch

1882. Preussisches Urkundenbuch. Politische Abteilung, Bd I/1, hrsg. von R. Philippi, C.B. Woelky, Königsberg.

Die Chronik Wigands von Marburg

1863. Die Chronik Wigands von Marburg, w: Scriptores rerum Prussicarum, hrsg. von T. Hirsch, M. Toeppen, E. Strehlke, Bd. 2, Leipzig.

David Lucas

1812. Preussische Chronik, t. 1, hrsg. von E. Hennig, Königsberg.

Grunau Simon

1876. Simon Grunau's Preussische Chronik, Bd.,1, hrsg. von M. Perlbach, R. Philippi, P. Wagner, Leipzig.

Hennenberger Caspar

1595. Erclerung der Preüssischen grössern Landtaffel oder Mappen etc., Königsperg in Preussen.

Leo Jan

2008. Dzieje Prus, Olsztyn.

Plastwici Johannes

1866. Chronicon de vitis Episcoporum Warmiensium, w: Scriptores rerum Warmiensium, Bd. 1, hrsg. von C.P. Woelky, J. M. Saage, Braunsberg.

Dusburg Petrus

2007. Petrus de Dusburgk, Chronica Terre Prusiae, red. J. Wenta, S. Wyszomirski, w: Monumenta Poloniae Historica, Nova Series, t. 13, Cracovia.

Praetorius Matthaeus

2006. Deliciae prussicae oder Preussische Schaubühne // Prusijos idomybes, arba Prusijos regykla, t. 3, hrsg. von I. Lukšaite, M. Girdzijauskaite, S. Drevello, J. Kiliumi, M. Čiurinsku, Vilnius.

Opracowania

Achremczyk S.

2011. Warmia, Olsztyn.

Białuński G.

2008. O zasiedleniu ziemi lubawskiej w okresie przedkrzyżackim $w$ świetle źródeł pisanych i toponomastycznych, Pruthenia, t. 4, ss. 289-320.

Cheleni J., Branthomme H.

1996. Boże drogi. Historia pielgrzymek chrześcijańskich, Warszawa. Eliade M.

2009. Traktat o historii religii, tłum. Jan Wierusz Kowalski, Warszawa.

Enders J. F.

1755. Tabula geographica episcopatum warmiensem in Prussia, Elbing.

Gerullis G.

1922. Die altpreussischen Ortsnamen, Berlin-Leipzig. 
Hochleitner J.

2006. Przydrożne pomniki kultu religijnego Świętej Lipki i okolic, Studia Angerburgica t. 11, ss. 78-91. Kawiński P.

2011. Organizacja pogańskiej przestrzeni sakralnej Prusów na tle osadnictwa w okresie pleKlimek R. miennym - przykład Pomezanii, Pogezanii i Warmii, Pruthenia, t. 6, ss. 89-128.

2015. Miejsca kultu Prusów na Warmii biskupiej, Komunikaty Mazursko-Warmińskie, nr 3 (289), ss. 365-386.

2016. Ślady średniowiecznej granicy Warmii między Reszlem a Świętą Lipką, Studia Geohistorica, nr 4, ss. 40-52.

Kopiczko A.

1993. Ustrój i organizacja diecezji warmińskiej w latach 1525-1772, Olsztyn.

Kosman M.

1976. Zanik pogaństwa w Prusach, Komunikaty Mazursko-Warmińskie, nr 1 (131), 1976, ss. 3-29.

Mažiulis V.

2013. Prūsų kalbos etimologijos žodynas, Vilnius.

Mierzyński A.

Olczyk A.

1892. Źródła do mytologii litewskiej, Warszawa.

Powierski T.

1961. Sieć parafialna biskupstwa warmińskiego do roku 1525, Lublin.

2003. Bogini Kurkö i niektóre aspekty społeczno-gospodarcze wierzeń Pruskich, w: Prussica. Artykuly wybrane z lat 1965-1995, t. 1, red. J. Trupinda, Malbork, ss. 129-149.

2003. Drugi tom stownika języka pruskiego, w: Prussica. Artykuly wybrane z lat 1965-1995, t. 1, Malbork, ss. 371-393.

Ptak J.

1997. Wojskowość średniowiecznej Warmii, Olsztyn.

Radzimiński A.

Röhrich V.

2011. Chrystianizacja i ewangelizacja Prusów. Historia i źródła, Toruń.

1901. Die Kolonisation des Ermlandes, Zeitschrift für die Geschichte und Altertumskunde Ermlands, Bd. 13, H. 1-2 (40-41), ss. 325-487.

1923. Die Kolonisation des Ermlandes, Zeitschrift für die Geschichte und Altertumskunde Ermlands, Bd 21, H. 1-4 (62-65), ss. 277-337, 394-411.

Smoczyński W.

2007. Słownik etymologiczny języka litewskiego, Wilno.

Szorc A.

1990. Dominium warmińskie 1243-1772. Przywilej i prawo chetmińskie na tle ustroju Warmii, Olsztyn.

Tidick E.

1926. Beiträge zur Geschichte der Kirchen-Patrozinien im Deutschordenslande Preußen bis 1525, Zeitschrift für die Geschichte und Altertumskunde Ermlands, Bd. 22, H. 1-3 (66-68), ss. 343-464.

Urbańczyk P.

2008. Władza i polityka we wczesnym średniowieczu, Wrocław.

Vanagas A.

1981. Lietuvių hidronimų etimologinis žodynas, Vilnius.

Топоров В. Н.

1975. Прусский языюк. Слоьарь А-Д, Москва. 
Robert Klimek

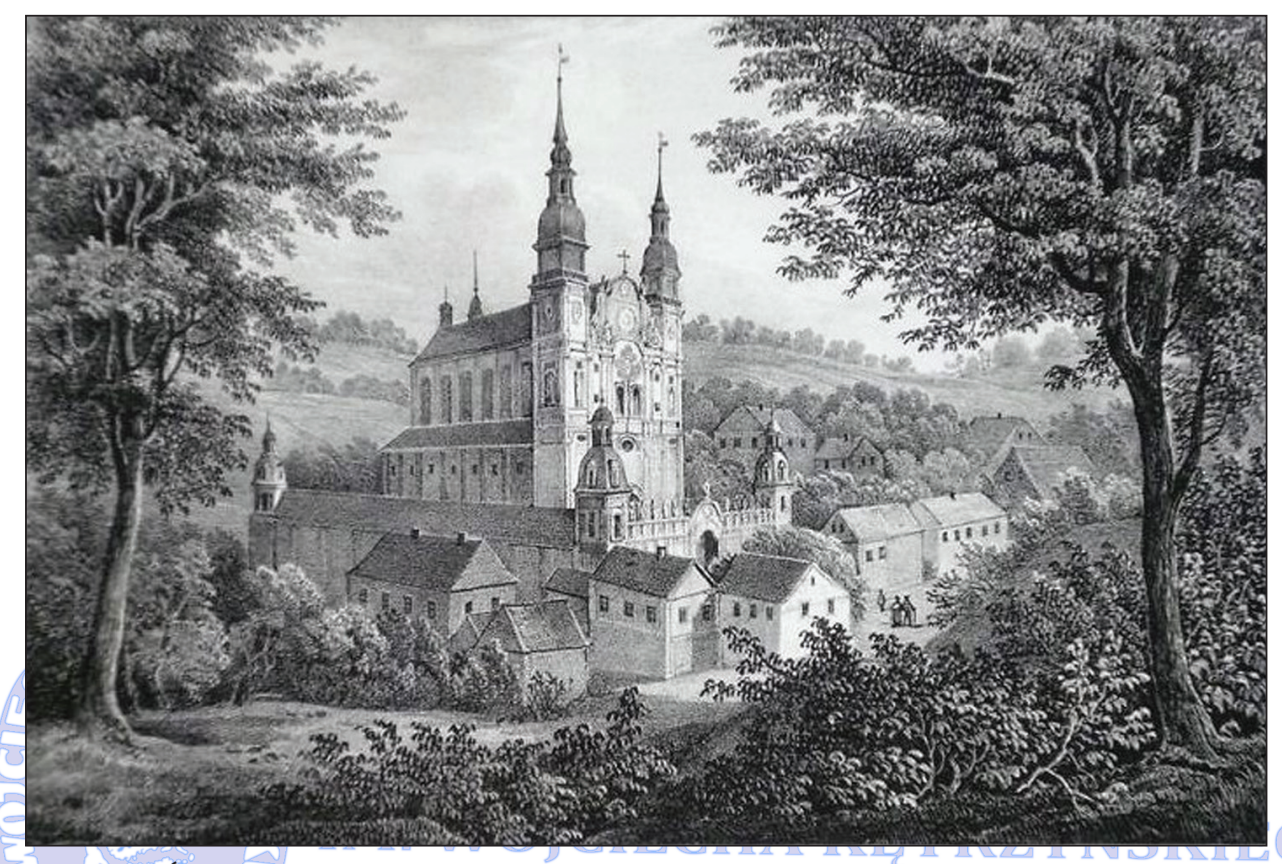

Klasztor w Swiętej Lipce, litografia z 1838 r.

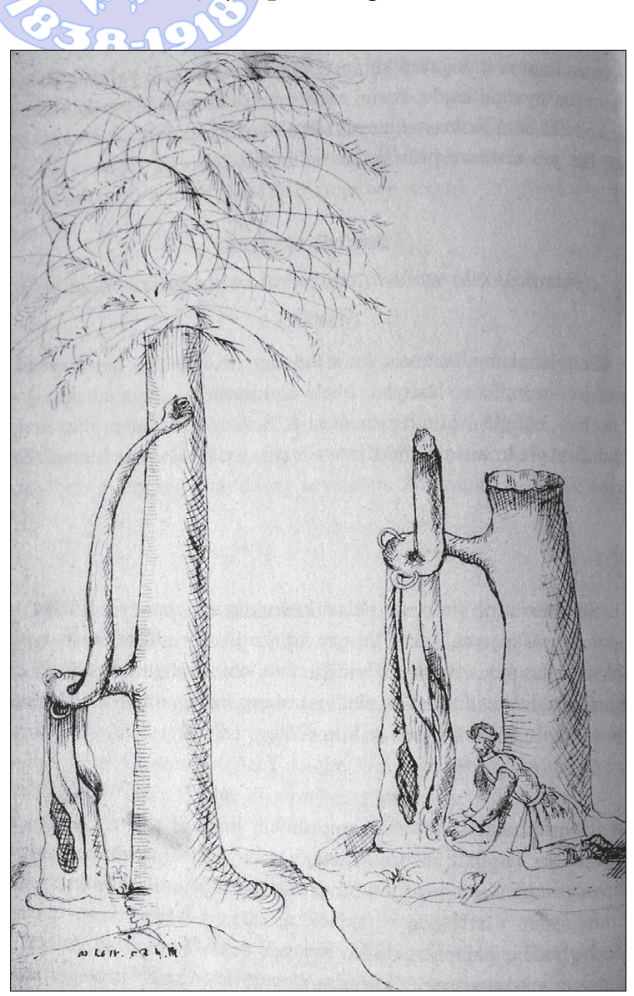

Drzewa zwane rombitami, według M. Praetoriusa 


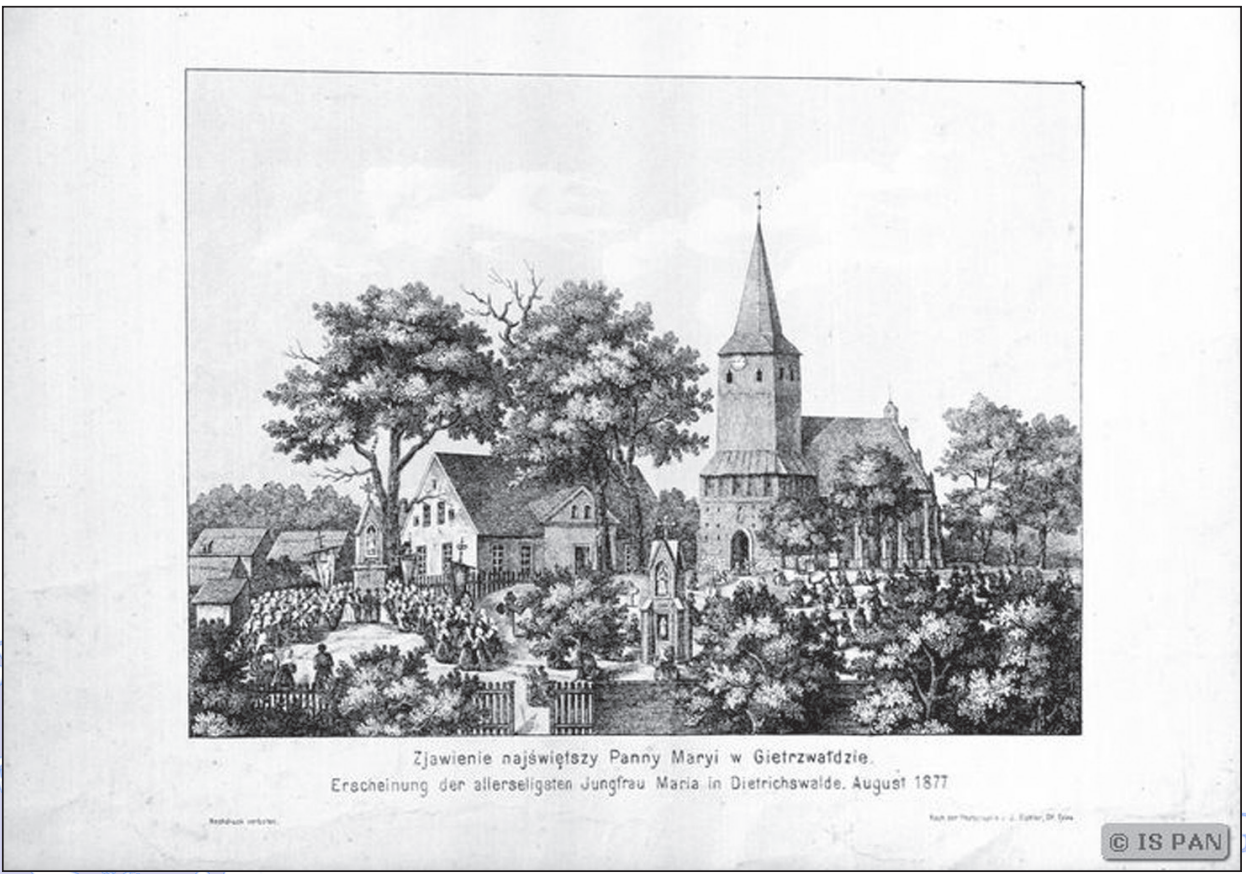

Objawienie NMP w Gietrzwałdzie w 1877 r., ze zbiorów IS PAN

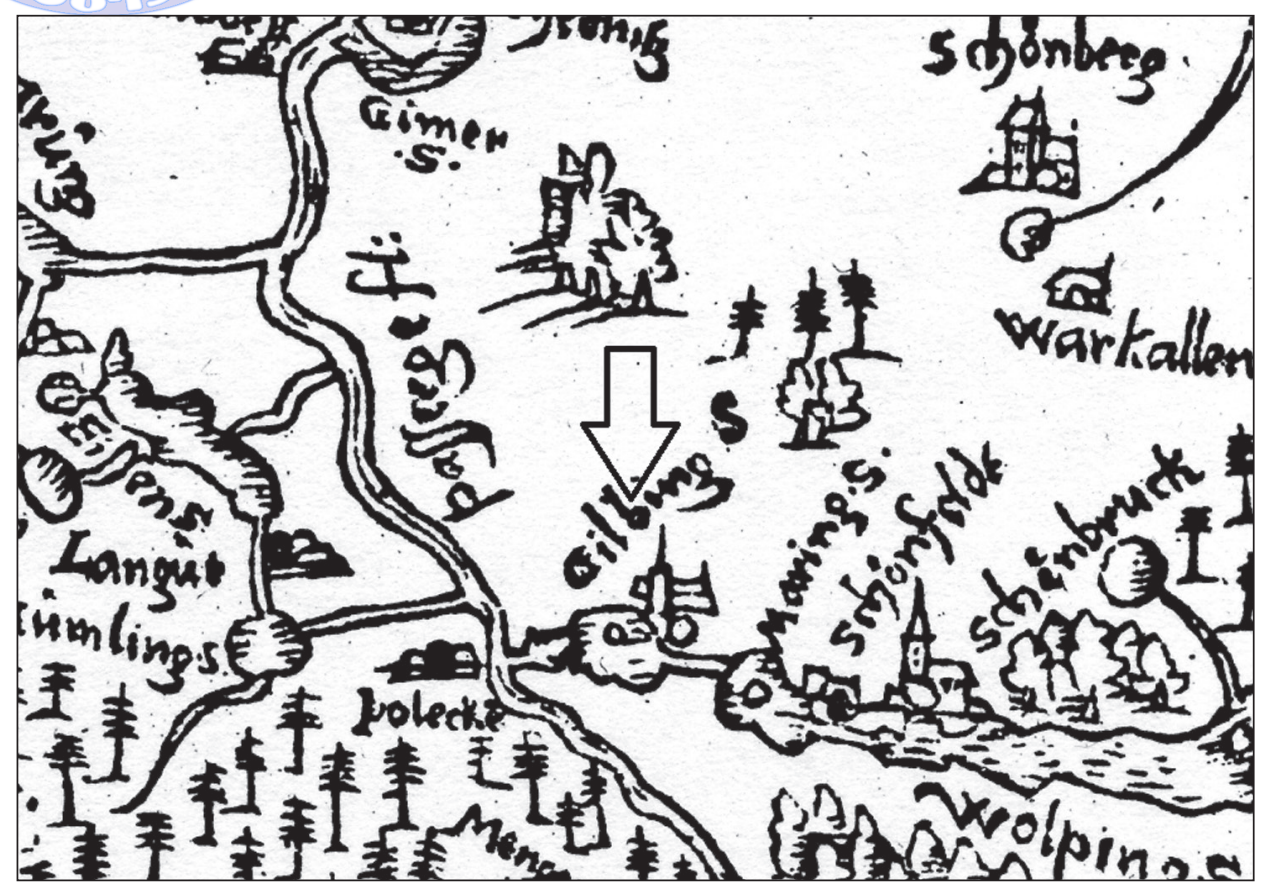

Jezioro Giłwy (Gilbing) i kościół w Gietrzwałdzie, mapa Kaspra Hennenbergera z 1576 r. (fragment) 